\title{
SOME ECONOMIC ASPECTS OF FRANCHISING IN THE USA
}

\author{
Yuliia Chaplynska', Varvara Piterska²
}

\begin{abstract}
The purpose of the article is to study the economic aspects of franchising in the USA. The subject of the study is some economic features of franchising activity in the USA. Research methodology. The research is based on the use of general scientific and special-scientific methods and techniques of scientific knowledge. The dialectical method allowed us to investigate the definition of franchising in the USA. Comparative legal method was used to compare legislative approaches to this issue. The statistical method was used to establish data that reflects the effectiveness of franchising activities. The method of system analysis helped to find out in which areas of economic activity franchising is most demanded. Interpretation of the content of the US legal acts governing issues related to franchising was realized with the help of the normative-dogmatic method. The system-structural method was used to study franchising in the USA as a single entity (system) with the coordinated functioning of all its elements. Methods of analysis and synthesis helped to study some economic aspects of the studied category to formulate further conclusions. Practical application. The positive experience of the USA in regulating issues related to franchising can be used for making appropriate changes to the Ukrainian legislation. Since franchising had originated and developed in this country, it is advisable to identify the key economic and some legal features of this area of business activity. Correlation/originality. This scientific work is the first research in Ukraine devoted not only to the general issues of franchising activity regulation, but specifically to the economic features of franchise activity in a separate country (in the USA).
\end{abstract}

Key words: franchising, economic indicators, franchisor, franchisee, pre-contractual disclose of information, the FTC Franchise Rule, FDD.

JEL Classification: F23, M21

\section{Introduction}

The beginning of the 21 st century is marked by a rapid development of information technology, which inevitably has caused the emergence of new institutions (Drozd, Inshin \& Mogilevskiy, 2018). One of these institutions is franchising as the new prospective area of business activity. Franchising, as a way of doing business, takes international forms in various industries. Today, many large enterprises create franchising companies in many countries. In just a few years, the franchise market has increased by several times. In many countries, this technology has given impetus to the development of the economy. The rapid growth of such sectors of the economy as food industry, electronics, automotive industry clearly demonstrates the effectiveness of franchising. The international franchise system creates favorable conditions for companies to enter the domestic markets of other countries by introducing their products through franchise firms.

Franchising has become one of the main distribution channels for products and services in developed

\footnotetext{
Corresponding author:

${ }^{1}$ Dnipropetrovsk State University of Internal Affairs, Ukraine.

E-mail: chaplynska yu@ukr.net

${ }^{2}$ Odessa National Maritime University, Ukraine.

E-mail: piterskavarvara@ukr.net
}

economies, where the image and reputation can determine the market share. Franchising is found in a wide variety of industries, such as fast food chains, retail sales of computer equipment, real estate services, car rental and maintenance stations, and these are just a few of the examples.

The USA remains a leader in the global franchising industry. Franchising and distribution continue to make up a large part of the United States economy. According to The Franchise Times, the top 200 largest franchise systems on its rankings had total annual sales in 2013 of $\$ 590$ billion. Among these systems are the likes of McDonald's, Kentucky Fried Chicken, 7-Eleven, Subway, Burger King, Pizza Hut, and Hertz. While these systems dominate the franchise landscape within the United States, they are part of the United States' larger franchise industry, which is estimated to consist of over 2,500 franchisors and, in 2014, nearly 770,000 franchise establishments. This size and breadth place the franchise industry as one of the United States' largest consumers and purchasers of 
commodities, sellers of other brand-name products, and employers.

The franchise industry within the United States shows no signs of slowing down. Since the recession years of 2007-2008, the franchise industry in the United States has continued to grow in a number of economic categories. In its recent Franchise Business Economic Outlook for 2015, the International Franchise Association (IFA), one of the leading franchise industry's trade associations, noted the consistent growth of the franchise industry since 2011 and projected that the growth of the output of franchise businesses would accelerate to $5.4 \%$ in 2015 and that the franchise sector's gross domestic product would increase by $5.1 \%$ and exceed the growth of the United States' gross domestic product. As recently as February 2015, the United States reportedly added 29,000 franchise jobs across various industries (Märzheuser-Wood \& Baggott, 2015).

\section{Literature review and research methodology}

The research is based on the use of general scientific and special-scientific methods and techniques of scientific knowledge. The dialectical method allowed us to investigate the definition of franchising in the USA. Comparative legal method was used to compare legislative approaches to this issue. The statistical method was used to establish data that reflects the effectiveness of franchising activities. The method of system analysis helped to find out in which areas of economic activity franchising is most demanded. Interpretation of the content of the US legal acts governing issues related to franchising was realized with the help of the normativedogmatic method. The system-structural method was used to study franchising in USA as a single entity (system) with the coordinated functioning of all its elements. Methods of analysis and synthesis helped to study some economic aspects of the studied category to formulate further conclusions.

The study of franchising as a type of international business was undertaken by N. V. Bezrukova, L. V. Voroniak, T. M. Hryhorenko, N. M. Hrushchynska, O. M. Kolodiziev, O. Ye. Kuzmin, A. M. Mahomedova, V. Ye. Sakharov, V. S. Tatarinov, T. M. Tsyhankova, A.V.Tsyrat, I.M. Shkola and others. However, this would be the first study in Ukraine devoted to franchising in the USA, and in particular, to the economic features of franchising in this country.

The concept of franchising is quite new for Ukraine, since it is not very common way of doing business in our country. This is due to the fact that the amendments to the Commercial Code of Ukraine, which enshrined the concept of commercial concession agreement (franchising), had been introduced only in 2015. There is no separate law that would regulate the issue of franchising in Ukraine, accordingly, everyone understands this concept in their own way, and therefore the possibility of making mistakes and inaccuracies when concluding franchise agreements is not excluded. Consequently, the purpose of this article is to study the economic aspects of franchising in the USA: the country, which is the undisputed leader in the international franchise sector.

\section{Presentation of the main material}

The first franchise of the model, which is currently in use appeared in the United States in 1850 by the aid of Singer Sewing Machine Company, which set up a sewing machine maintenance network. The first franchise agreement was also concluded in the U.S. by Howard Johnson, who in 1932 decided to create a chain of his corporate restaurants. By the end of 1936 the number of such restaurants was 41 .

In 1950s the interest in franchising was growing significantly, its concept was taken over by an increasing number of enterprises in various sectors of the economy. For example, McDonald's, which is probably the largest franchisor in the world, was founded in California in 1948. In 1954, it sold its first franchise, and now has more than 30,000 restaurants of this brand in 118 countries.

In 1960 the International Franchising Association (IFA) was established in Washington to protect and promote the interests of the franchise industry. This Association has adopted its own Code of Ethics, the main purpose of which is to regulate the relations, which arise in the franchising activities, as well as to introduce best practices for their regulation. Although the Code is not specifically designed to deal with each situation, it contains general rules, which will help to avoid problems or to resolve conflicts.

Membership in the IFA is optional but desirable; the majority franchisors are the members of this organization. IFA provides its members with up-to-date information on franchising activities, including the latest legal developments, information on the opportunities and benefits of this kind of business activity.

Many franchisees and franchisee associations are members of the American Association of Franchisees and Dealers (the "AAFD"). The AAFD is organized by the formation of exclusive Trademark Chapters representing all of the franchised systems for which we have a significant number of members. The Association's Trademark Chapters provide a crucial service of helping franchise systems throughout the United States develop consensus decisions within their franchise systems and to promote more equitable franchise relationships which exhibit the AAFD's goal of Total Quality Franchising. The AAFD has formed our exclusive trademark chapters for more than 60 franchise systems, with the goal of having an affiliated chapter for every franchise system in the USA (American Association of Franchisees and Dealers).

In 1996 the AAFD unveiled the first ever balanced standards of Fair Franchising Practices for the 
franchising community. Franchise buyers now have objective criteria by which to judge a franchise opportunity. The AAFD's Fair Franchising Standards also serve as the basis for accrediting forward thinking franchisors who recognize that AAFD endorsement of their franchising practices can pay enormous dividends in the franchising marketplace. Over the past 16 years the AAFD has promulgated over 140 Fair Franchising Standards and commentary to give guidance to fair and balanced franchise agreements and relationships. The AAFD Fair Franchising Standards are now published in both print and Kindle editions and are available worldwide (American Association of Franchisees and Dealers).

Nowadays United States franchised business directly accounts for more than 733,000 establishments that support nearly 7.6 million direct jobs, $\$ 674.3$ billion of economic output for the U.S. economy and 3 percent of Gross Domestic Product. Franchising had not only emerged in the USA, but has found success across virtually every culture on Earth. Because America is the world's most mature and sophisticated franchise market, use of the franchise model internationally is a competitive advantage for U.S. exports, agriculture, manufacturing, and supply chains. According to the U.S. Bureau of Economic Analysis, franchise fees have an overwhelmingly (34 to 1) positive impact on America's trade balance. The international growth of franchises acts as a significant export multiplier, with many other U.S. goods and services flowing through the door opened by the franchise agreements and further driving the U.S. employment (U.S. Commercial Service, 2018).

The issue of franchising in the USA is regulated at both the federal and state levels.

At the federal level, the issue under study is regulated by the FTC Franchise Rule 16 CFR Part 436. The Franchise Rule gives prospective purchasers of franchises the material information they need in order to weigh the risks and benefits of such an investment. The Rule requires franchisors to provide all potential franchisees with a disclosure document containing 23 specific items of information about the offered franchise, its officers, and other franchisees.

According to Paragraph (h) of $\$ 436.1$ "Definitions" franchise means any continuing commercial relationship or arrangement, whatever it may be called, in which the terms of the offer or contract specify, or the franchise seller promises or represents, orally or in writing, that:

(1) The franchisee will obtain the right to operate a business that is identified or associated with the franchisor's trademark, or to offer, sell, or distribute goods, services, or commodities that are identified or associated with the franchisor's trademark;

(2) The franchisor will exert or has authority to exert a significant degree of control over the franchisee's method of operation, or provide significant assistance in the franchisee's method of operation; and
(3) As a condition of obtaining or commencing operation of the franchise, the franchisee makes a required payment or commits to make a required payment to the franchisor or its affiliate (the Franchise Rule).

By virtue of the Supremacy Clause in the United States Constitution, the FTC Rule, which is focused primarily on disclosure of material facts, applies in each of the 50 states, the District of Columbia, and all U.S. territories. In addition to the FTC Rule, 24 states have their own franchise disclosure and relationship laws (Märzheuser-Wood \& Baggott, 2015).

At the state level, there is no uniform legal definition of a "franchise". Rather, the states define "franchise" in several different ways. For example, in California, Illinois, Indiana, Iowa, Maryland, Michigan, North Dakota, Oregon, Rhode Island, Virginia, Washington, and Wisconsin, a business arrangement qualifies as a "franchise" if, under the terms of the agreement:

(1) a franchisee is granted the right to offer, sell, or distribute goods or services, under a marketing plan or system prescribed or suggested in substantial part by a franchisor;

(2) the operation of the franchisee's business pursuant to such plan or system is substantially associated with the franchisor's trademark, service mark, trade name, logotype, advertising, or other commercial symbol designating the franchisor or its affiliate; and

(3) the person granted the right to engage in such business is required to pay to the franchisor or an affiliate of the franchisor, directly or indirectly, a franchise fee of $\$ 500$ or more.

A second group of states vary from the model by identifying a "community of interest" as an element rather than a "marketing plan" (e.g., Hawaii, Minnesota, Mississippi, Nebraska and South Dakota follow this model). A "community of interest" means a continuing financial interest between the franchisor and franchisee in the operation of the franchise business.

A third group of states, including Connecticut, Missouri, New York and New Jersey, use "two-pronged" definitions of a "franchise" (contrast this with the "three-pronged" federal definition) (Rosen, Salis \& Karol, 2019).

The law does not impose any restrictions on the franchisor's organizational form, but the most widespread organizational form in the USA are the corporation and the limited liability company ("LLC"). The choice depends on the legal, financial and tax requirements of the franchisor. However, a limited liability company is currently the preferred form of business because it offers franchisors a number of benefits. For example, there are fewer formalities in management, flexibility in revenue sharing and the ability to transfer assets from a legal entity.

Unlike corporations, LLCs: (1) can have an unlimited number of domestic or foreign members with different classes of ownership and who can (if they elect so) 
manage the LLC's business affairs; and (2) are not subject to strict corporate governance requirements, such as scheduling regular owners' meetings and maintaining corporate minute books. For taxation purposes, LLCs are treated as pass-through entities, unless they elect to be taxed as a $\mathrm{C}$ corporation. Therefore, all the profits and losses of the LLC pass through the business to the LLC members. The members report these profits and losses on their personal tax returns; thus, the LLC does not pay federal income taxes; however, some states do charge the LLC itself a tax. Therefore, double taxation is avoided (Rosen et al., 2018).

US franchisors typically use a base unit franchise structure in which the franchisor grants the franchisee one franchise agreement for each franchised unit. Franchisors can combine the unit franchise structure with a multi-unit structure, most typically an area development or area representation structure.

Many US franchisors use master franchise agreements when expanding internationally. They contract with a local entity (master franchisee) to develop the franchisor's brand in a particular geographic area according to an agreed schedule, through unit franchise agreements entered into between the master franchisee and its affiliates or third parties (Woods \& Hurwitz, 2018).

There is a statutory obligation to disclose information before concluding a franchise agreement in the USA. Thus, in accordance with Paragraph (d) of $\$ 436.1$ of the Franchise Rule "Disclose" means to present all material facts accurately, clearly, concisely, and legibly in plain English. All information to be provided should be arranged in a single document, which is called "Franchise Disclose Document”. This document is provided at least 14 calendar-days before signing a binding agreement with or making any payment to the franchisor or an affiliate in connection with the proposed franchise sale.

The FDD contains 23 specific items, which the franchisor should disclose to the potential franchisee: Item 1: The franchisor and any parents, predecessors and affiliates. This section provides a description of the company and its history. Item 2: Business experience. This section provides biographical and professional information about the franchisors and its officers, directors, and executives. Item 3: Litigation. This section provides relevant current and past criminal and civil litigation for the franchisor and its management. Item 4: Bankruptcy. This section provides information about the franchisor and any management who have gone through a bankruptcy. Item 5: Initial fees. This section provides information about the initial fees and the range and factors that determine the amount of the fees. Item 6: Other fees. This item provides a description of all other recurring fees or payments that must be made. Item 7: Initial investment. This item is presented in table format and includes all the expenditures required by the franchisee to make to establish the franchise. Item 8: Restriction on sources of products and services. This section includes the restrictions that franchisor has established regarding the source of products or services. Item 9: Franchisee's obligations. This item provides a reference table that indicates where in the franchise agreement franchisees can find the obligations they have agreed to. Item 10: Financing. This item describes the terms and conditions of any financing arrangements offered by the franchisor. Item 11: Franchisor's Assistance, Advertising. Computer Systems and Training. This section describes the services that the franchisor will provide to the franchisee. Item 12: Territory. This section provides the description of any exclusive territory and whether territories will be modified. Item 13: Trademarks. This section provides information about the franchisor's trademarks, service and trade names. Item 14: Patents, copyrights and proprietary information. This section gives information about how the patents and copyrights can be used by the franchisee. Item 15: Obligation to participate in the actual operation of the franchise business. This section describes the obligation of the franchisee to participate in the actual operation of the business. Item 16: Restrictions on what the franchisee may sell. This section deals with any restrictions on the goods and services that the franchisee may offer its customers. Item 17: Renewal, termination, transfer, and dispute resolution. This section tells you when and whether your franchise can be renewed or terminated and what your rights and restrictions are when you have disagreements with your franchisor. Item 18: Public Figures. If the franchisor uses public figures (celebrities or public persons), the amount the person is paid is revealed in this section. Item 19: Financial Performance Representations. Here the franchisor is allowed, but not required, to provide information on unit financial performance. Item 20: Outlets and Franchisee Information. This section provides locations and contact information of existing franchises. Item 21: Financial statements. Audited financial statements for the past three years are included in this section. Item 22: Contracts. This item provides of all the agreements that the franchisee will be required to sign. Item 23: Receipts. Prospective franchisees are required to sign a receipt that they received the FDD ( $\$ 436.4$ of the Franchise Rule).

The information should be disclosed clearly, legibly, concisely in a single document using plain English and respond fully to each disclosure item. The disclosures must be in a form that permits each prospective franchisee to store, download, print, or otherwise maintain the document for future reference.

All information in the disclosure document shall be current as of the close of the franchisor's most recent fiscal year. After the close of the fiscal year, the franchisor shall, within 120 days, prepare a revised disclosure document, after which a franchise seller may distribute only the revised document and no other disclosure document. 
Under the US law, a franchisor cannot sell a franchise until it provides the potential franchisee with the document containing all information concerning its activity (FDD). Besides, 14 states require franchisors to register their FDD documents in the relevant state depertment, or notify them in advance of a franchise offer to a potential franchisee before starting any franchising activity within the state.

Any unfair or deceptive act or practice in violation of pre-disclose requirement imposed by the Franchise Rule is a violation of the US Federal Trade Commission Act, which was adopted in 1914 to give the US government a full complement of legal tools to use against anticompetitive, unfair, and deceptive practices in the marketplace (Federal Trade Commission Act). Section 5 of the Trade Commission Act provides responsibility for unfair methods of competition in or affecting commerce, and unfair or deceptive acts or practices in or affecting commerce.

Under the Franchise Rule FTC is provided with the right to bring an action against franchisors who violate the Rule in federal court and to seek any or all of the following remedies: (1) civil penalties of up to $\$ 11,000$ per violation; (2) injunctive relief with respect to violations of the FTC Franchise Rule, including barring franchise sales in the United States; and (3) restitution, rescission, or damages on behalf of the affected franchisees.

However, the Franchise Rule does not apply to all franchise agreements. Thus, $\$ 436.8$ of this act contains seven exemptions, when the provisions of part 436 shall not apply: (1) The total of the required payments, or commitments to make a required payment, to the franchisor or an affiliate that are made any time prior to or within six months after commencing operation of the franchisee's business is less than $\$ 570$. (2) The franchise relationship is a fractional franchise. Fractional franchise means a franchise relationship that satisfies the following criteria when the relationship is created: (a) The franchisee, any of the franchisee's current directors or officers, or any current directors or officers of a parent or affiliate, has more than two years of experience in the same type of business; and (b) The parties have a reasonable basis to anticipate that the sales arising from the relationship will not exceed $20 \%$ of the franchisee's total dollar volume in sales during the first year of operation. (3) The franchise relationship is a leased department. Leased department means an arrangement whereby a retailer licenses or otherwise permits a seller to conduct business from the retailer's location where the seller purchases no goods, services, or commodities directly or indirectly from the retailer, a person the retailer requires the seller to do business with, or a retailer-affiliate if the retailer advises the seller to do business with the affiliate. (4) The franchise relationship is covered by the Petroleum Marketing Practices Act, 15 U.S.C. 2801. (5) (a) The franchisee's initial investment, excluding any financing received from the franchisor or an affiliate and excluding the cost of unimproved land, totals at least $\$ 1,143,100$ and the prospective franchisee signs an acknowledgment verifying the grounds for the exemption. (b) The franchisee (or its parent or any affiliates) is an entity that has been in business for at least five years and has a net worth of at least $\$ 5,715,500$. (6) One or more purchasers of at least a $50 \%$ ownership interest in the franchise: within 60 days of the sale, has been, for at least two years, an officer, director, general partner, individual with management responsibility for the offer and sale of the franchisor's franchises or the administrator of the franchised network; or within 60 days of the sale, has been, for at least two years, an owner of at least a $25 \%$ interest in the franchisor. (7) There is no written document that describes any material term or aspect of the relationship or arrangement.

Under the franchise agreement or the franchisor's practice, the franchisor has the right to bind the franchisee to purchase or lease goods, services, supplies, fixtures, equipment, inventory, computer hardware and software, real estate, or comparable items related to establishing or operating the franchised business either from the franchisor, its designee, or suppliers approved by the franchisor, or under the franchisor's specifications.

Franchisees can challenge a sourcing requirement as an illegal tie under the anti-trust laws. Under a tying arrangement, the seller conditions the sale of one product (tying product) on a requirement that the buyer also purchase another unwanted product (tied product) from the seller. In franchising, the tying product is typically alleged to be the franchise itself and the tied product is the item that the franchisor requires the franchisee to purchase (Woods \& Hurwitz, 2018).

The franchisor receives for franchise selling a fee from the franchisor, which, in accordance with the Franchise Rule, may be in the form of initial fee (the fee paid to the franchisor in exchange for establishing the franchise relationship, along with the provision of some initial services; this fee is paid in a lump sum to the franchisor when a franchise agreement is signed) and other fee (royalties, and fees for lease negotiations, construction, remodeling, additional training or assistance, advertising, advertising cooperatives, purchasing cooperatives, audits, accounting, inventory, transfers, and renewals).

These fees usually include: (1) an initial franchise fee; (2) an ongoing royalty fee; and (3) advertising fund contributions. Typically, the initial fee is paid up front simultaneously upon the execution of the franchise agreement. The royalty fees are typically paid on a monthly basis, for the ongoing use of the franchisor's trademarks and for the services that the franchisor provides. The typical range for royalties may be from 4 percents to 8 percents of the franchisee's gross revenues, although sometimes flat-rate fees are 
charged. As many franchisors in the US create a national advertising fund (or sometimes a regional advertising fund), franchisees are often required to make regular contributions to the fund. The typical range of these fees is from 1 percent to 3 percents of the franchisee's gross revenues, with 2 percents being fairly common (Rosen et al., 2018).

\section{Conclusion}

The USA is the world's largest "franchise country", characterized by the highest level of development of special franchise legislation, abundant jurisprudence on franchising, and an extensive franchise legal theory. Much longer history of franchising in the United States has allowed the public and all branches of government at all its levels to identify the advantages and disadvantages of franchising better than it was done in other countries.

$40 \%$ of the total turnover in the USA is generated by the companies created under the franchising system, and their number is constantly growing. For comparison, in Europe, the share of such enterprises in the market is varying from $5 \%$ to $30 \%$.

Franchising had not only originated in the USA; today, the U.S. franchise system is the largest in the world. If we analyze the dynamics of the development of franchising in the United States, we can conclude that historically franchising here is one of the most advanced and successful forms of organizing and developing business. The centuries of experience in the existence of franchising in the United States proved its stability and ensured its popularity.

In the USA, franchising is governed by federal and state laws. The most important legal act that regulates the implementation of franchise activities is the FTC Franchise Rule, which operates both at the federal and state levels.

All information that the franchisee should obtain before concluding the franchise agreement is arranged into one document - the "Franchise Disclose Document" (FDD). The purpose of this document is to provide potential franchisee with the information about the franchisor, the franchise system and the agreements that must be signed so that the franchisee could take a balanced decision in the future.

Most US franchise systems, in addition to lumpsum payments, require the franchisee to pay regular contributions (royalties), as well as advertising fund contributions.

\section{References:}

American Association of Franchisees and Dealers. Fair Franchising Standards. Retrieved from: https://www.aafd.org/fairness-initiatives/fair-franchising-standards/

American Association of Franchisees and Dealers. Fairness Initiatives - "Your Center for Total Quality Franchising”. Retrieved from: https: //www.aafd.org/fairness-initiatives/

Drozd, O. Y., Inshin, M. I., \& Mogilevskiy, L. V. (2018). The issue of cryptocurrency legal regulation in ukraine and all over the world: comparative analysis. Baltic Journal of Economic Studies, vol. 4, no. 1, pp. 169-174. doi: $10.30525 / 2256-0742 / 2018-4-1-169-174$

Federal Trade Commission Act [Chapter 311 of the 63rd Congress, 38 Stat. 717, September 26, 1914 as Amended Through Public Law 111-203, Enacted July 21, 2010]. Retrieved from: https://legcounsel.house.gov/Comps/ Federal\%20Trade\%20Commission\%20Act.pdf

Franchise Rule 16 CFR Part 436 as of November 27, 2019. Electronic Code of Federal Regulations. Retrieved from: https://www.ecfr.gov/cgi-bin/text-idx?SID =e37d3cd088c6b4724a389338f9c3e141\&mc=true\& tpl=/ecfrbrowse/Title16/16cfr436_main_02.tpl

Märzheuser-Wood, B., \& Baggott, B. (2015). Franchise Law in the United States. Dentons. Retrieved from: https://www.dentons.com/en/insights/articles/2015/june/12/franchise-law-in-the-united-states

Rosen, R. et al. (2018). United States. In M. Abell (Ed.) The Franshise Law Review. Edition 5. London: Law Business Research Ltd., pp. 621-661.

Rosen, R., Salis, L., \& Karol, J. USA: Franchise 2020. Retrieved from: https://iclg.com/practice-areas/franchiselaws-and-regulations/usa

U.S. Commercial Service (2018). Franchising Industry A Reference for U.S. Exporters. Retrieved from: https://www.franchise.org/sites/default/files/2019-05/USCS_Franchising_Resource_Guide_2018.pdf

Woods, W., \& Hurwitz, A. (2018). Domestic and international franchising, master franchising, and regulation of franchise agreements in the United States: overview. Thomson Reuters Practical Law. Retrieved from: https: //uk.practicallaw.thomsonreuters.com/8-631-2421 ?transitionType=Default\&contextData=(sc.Default) \&firstPage $=$ true $\& \mathrm{bhcp}=1$ 